\title{
3D Nanostructured Porous Layer of Ammonium Nitrate: Influence of the Moisturizing Method on the Layer's Structure
}

\author{
A.E. Artyukhov, V.I. Sklabinskyi \\ Sumy State University, 2, Rymskogo-Korsakova st., 40007 Sumy, Ukraine
}

(Received 21 September 2016; published online 29 November 2016)

\begin{abstract}
The paper deals with the influence of humidifier type and humidification method on structure and quality of porous surface layer of ammonium nitrate granules. Different types of humidifiers are propose and the qualitative characteristics of porous ammonium nitrate for each of them are shown. The structure and quality parameters of porous ammonium nitrate with different mutual direction of movement of granules and humidifier. A method for granules pre-wetting with its heat treatment in vortex granulator is proposed. Obtained data are basis for technique of vortex granulators engineering calculation consisting units of 3-D nanostructured porous surface layer on granule ammonium nitrate obtaining.
\end{abstract}

Keywords: 3D Nanostructured porous layer, Vortex granulator, Voisturizing

DOI: 10.21272/jnep.8(4(1)).04051

PACS numbers: 89.20.Bb, 89.20.Kk

\section{INTRODUCTION}

In world practice bulk industrial explosives are mostly manufactured using the special porous ammonium nitrate (PAN) [1-3]. Bulk industrial explosives are widely adopted in blasting operations to replace more dangerous and expensive trinitrotoluene containing industrial explosives. PAN provides a more complete chemical reactions during the explosion due to the greater (compared with an ordinary ammonium nitrate) surface contact with the diesel fuel. With nanosized porous structure creation on surface and inside of PAN granules it becomes possible to hold diesel fuel (diesel fuel molecule size is $4 \mathrm{~nm}$ ). Pore system of curvilinear channels can saturate PAN granule diesel fuel in an amount which is sufficient for successful blasting.

PAN is also the base of emulsion industry explosives [4-7].

At present introduction of PAN in production of blasting is limited by lack in Ukraine its own production (up to $80 \%$ PAN are purchased in Russia).

The use of vortex granulators for PAN obtaining as a component of industrial explosives such as ANFO (Ammonium Nitrate / Fuel Oil) is a new direction in granulation technology [8]. A distinctive feature of vortex granulators is their versatility, which allows to receive PAN in various ways:

- heat treatment and hydration of granules directly into the granulator;

- preliminary humidification in a separate unit and heat treatment in vortex granulator.

Theoretical description and experimental study of some aspects of granulation in vortex granulators is given in a list of works, which describe the hydrodynamics of flows traffic $[9,10]$, granules classification and separation processes [11], environmental aspects of development unit of utilizing modules for production waste [12-14], hydrodynamic and thermodynamic conditions for PAN obtaining [15, 16].

\section{DESCRIPTION OF OBJECT AND METHODS OF RESEARCH}

According to the tasks of experimental research of laboratory of Processes and Equipment of Chemical and Petroleum-Refineries Department of Sumy State University experimental device was designed, structure of which is shown in fig. 1.

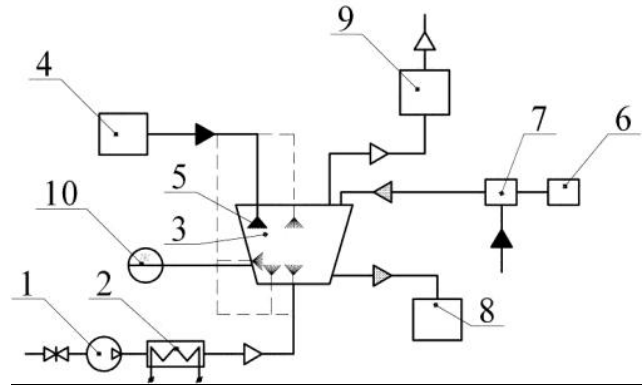

Fig. 1 - Experimental stand of research of thermodynamic working conditions of granulator:, principle diagram of the stand (a), diagram of temperature measurement using thermal imager (b); 1 - gas blower; 2 - heater; 3 - vortex granulator; 4 - container for preparation of humidifier; 5 nozzle; 6 - container for granules; 7 - pre-wetting capacity (used for humidifying); 8 - container of commodity granules; 9 - waste gas cleaning stage (bubbler); 10 - selfrecorder registration potentiometer; The dotted line shows the nozzle installation variants

Devices and equipment:

- temperature measurement in air heater - thermo vapor potentiometer registers selfrecording;

- measurement of granulator workspace temperature - thermal imager Fluke Ti25;

- measurement of moisture granules - Multimeter DT-838;

- measurement of granules' strength extensometer, device for measuring the strength;

- measurement of retention granules - small-sized centrifuge corner;

- study of the microstructure of pellets - microscope KONUSPIX-450X KONUS, scanning electron microscope SEM-100U and X-ray spectrometer with an energy dispersion. 


\section{RESULTS AND DISCUSSIONS}

Comparative characteristics of granules surface structure is presented in fig. 2.

Experimental studies highlight in the structure of ammonium nitrate granules such types of pores [15]:

- cracks

- chips;

- caverns;

- channels.
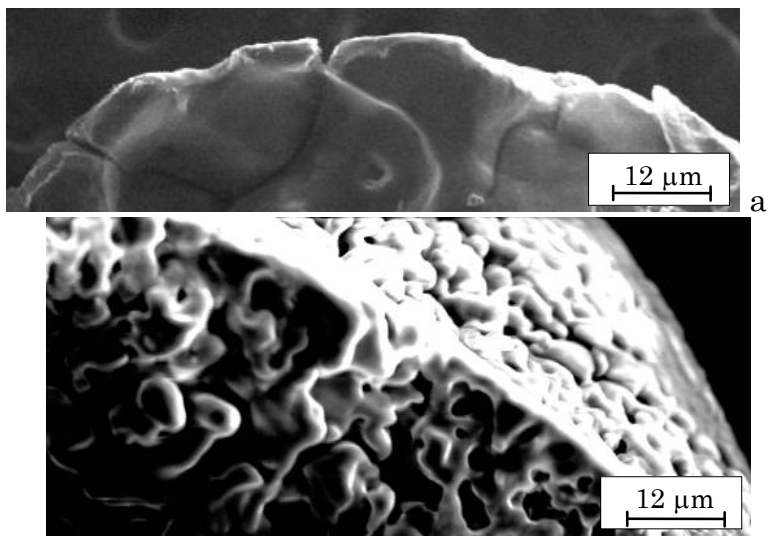

b
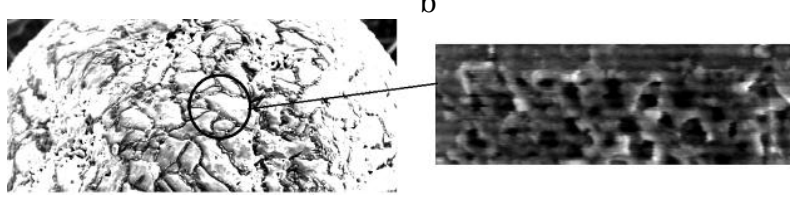

Fig. 2 - The structure of ammonium nitrate granules: a - surface layer of dry granule (ammonium nitrate before humidification); b - surface layer of granule after humidification and heat treatment; $\mathrm{c}$ - granule after humidification and heat treatment with diesel fuel at surface and in pores
Regardless of humidification method on granule`s surface typical sectors, that are shown in fig.3, are formed. The ratio between the areas of these sectors for each humidification method is different. The more uniform the initial contact of granules with a humidifier, the smaller nonporous surface area and a large surface area with deep pores.

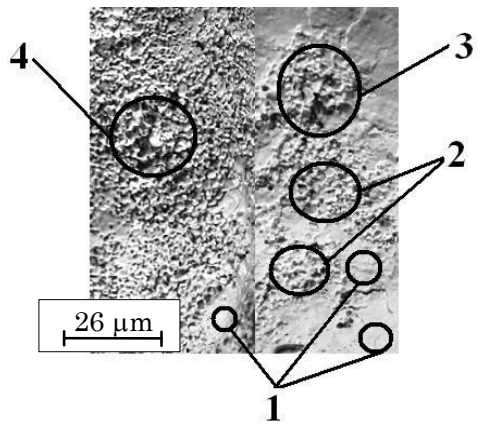

Fig. 3 - The main areas on PAN granules surface: 1 - area without pores; 2 - area with surface pores; 3 - area with small depth pores; 4 - area with deep pores (x380)

The results of humidification method effect research (nozzle installation place and mutual direction of flow of granules and liquid) on granule's structure and quality are shown in Table 1.

At the top supply of humidifier in center of unit due to action of counter swirling gas flow uniformity of moisturizing is greatly reduced. In this case granule surface has a large number of non-porous areas, porous layer does not extend deep into granule.

Humidifier moving to peripheral area contributes to excessive granules' humidification. Excessive humidification leads to formation of cracks and cavities due to sharp release of water to granules' surface (fig. 4).

Table 1 - Effect of humidification method on granule's structure and quality (humectant - water, thermodynamic and hydrodynamic characteristics of granulator operation according to [8])

\begin{tabular}{|l|c|c|c|c|c|}
\hline \multicolumn{1}{|c|}{ Humidification method } & $\begin{array}{c}\text { Strength, } \\
\text { kg / } \\
\text { granule }\end{array}$ & $\begin{array}{c}\text { Absorption } \\
\text { capacity, \% }\end{array}$ & $\begin{array}{c}\text { Relative } \\
\text { Holding } \\
\text { carea of } \\
\text { pority, \% } \\
\text { porous } \\
\text { surface, }\end{array}$ & $\begin{array}{c}\text { Relative depth of } \\
\text { porous layer, the } \\
\text { layer depth mm / } \\
\text { radius granule }\end{array}$ \\
\hline $\begin{array}{l}\text { Humidifier dispersing in } \\
\text { granulator: }\end{array}$ & \multicolumn{5}{|l|}{} \\
\hline - top supple in device center & 0,45 & 7,9 & 6,2 & 68 & $0,1-0,15$ \\
\hline $\begin{array}{l}\text { - top supply of humidifier in } \\
\text { peripheral areas } \\
\text { (directly on surface of vortex } \\
\text { fluidized bed) }\end{array}$ & 0,45 & 8 & 6,5 & 74 & $0,1-0,15$ \\
\hline - horizontal supply in fluidized bed & 0,43 & 8,1 & 7,3 & 79 & $0,15-0,25$ \\
\hline - bottom supply in device center & 0,43 & 8,1 & 6,8 & 72 & $0,1-0,2$ \\
\hline $\begin{array}{l}\text { - bottom supply in peripheral areas } \\
\text { (directly on surface of vortex } \\
\text { fluidized bed) }\end{array}$ & 0,4 & 8,2 & 8,1 & 84 & $0,2-0,3$ \\
\hline Pre-wetting by methods [17, 18] & 0,4 & 8,3 & 9,6 & 91 & $0,3-0,4$ \\
\hline
\end{tabular}

In top humidifier supply of humidifier in peripheral areas of device granule's contact evenness with liquid increases and nanoscale porous areas, formed on the surface and within the granules, appears. These areas have mixed structure: pores are combined with small cracks that were formed due the partial excess moisture on granule's surface. When horizontal supply of humidifier in granule's fluidized bed and lower supply of humidifier to device's center nanoscale porous layer has prevailing spread on granule's surface and inside it. In this case the pores are located only on surface, the structure is 


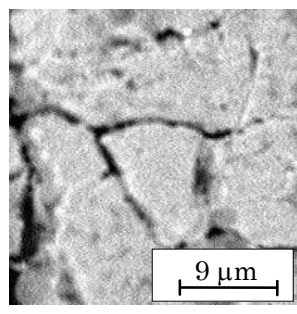

a

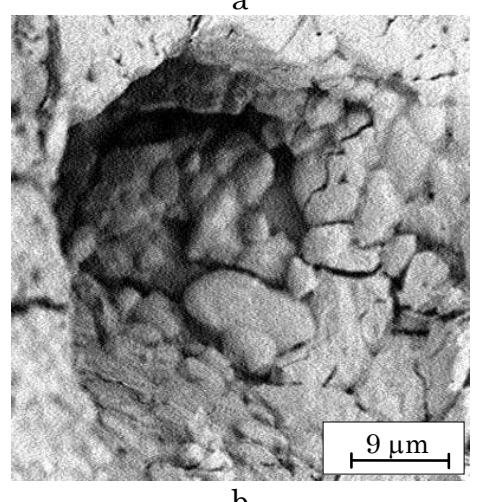

Fig. 4 - Formation of cracks (a) and cavities (b) in granules surface excess humidification

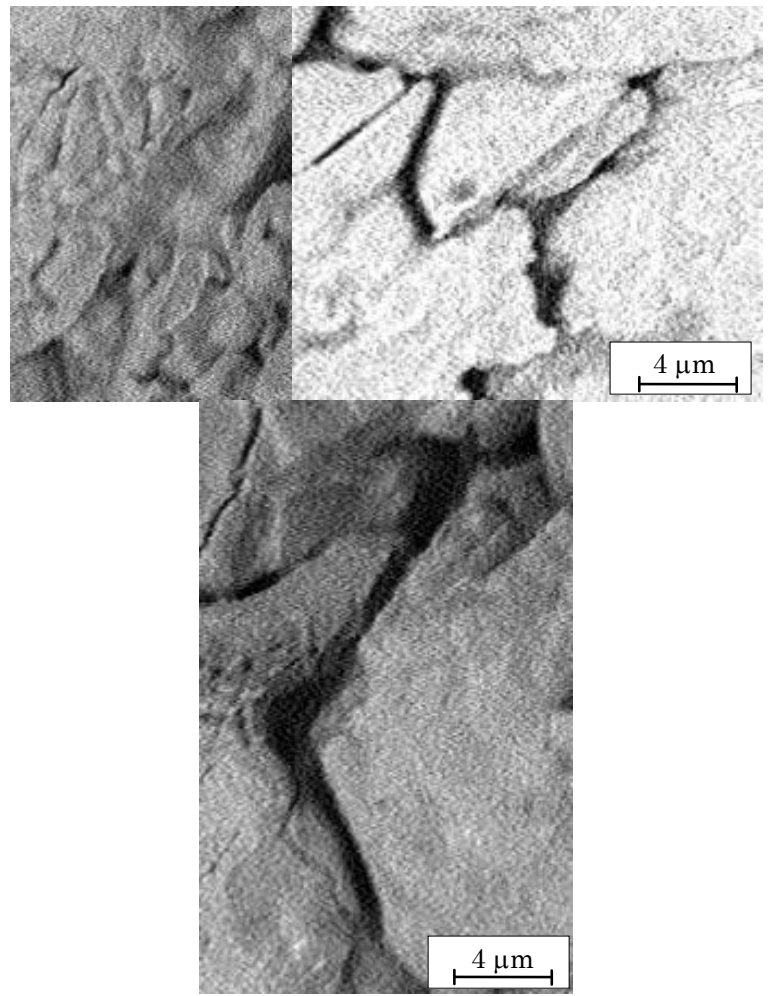

Fig. 5-Granule's structure at horizontal supply of humidifier to granule's fluidized bed and lower supply of humidifier to center of unit

dominated by straight channels granules (fig. 5), which don't hold effectively diesel fuel.

When bottom supply of humidifier in granulator`s peripheral areas relative nanoscale porous layer is increased compared with other methods of humidifier supplying. In this case the pores in nanoscale layer have small depth, which reduces the ability to retain granules diesel. In the porous layer structure curved channels begin to appear (fig. 6).

Analysis of obtained research results allowed us to offer new ways to produce granules with porous structure $[17,18]$, which allows to reduce the influence of destabilizing factors on formation of nano-sized porous surface layer. In the base of developed improved granules humidification process methods with predetermined amount of moisture before it enters the vortex weighted layer and the beginning of exposure to high temperature vortex flow of coolant. This solution allows the simultaneous occurrence of drying and pore formation process, helps to reduce granules residence time in the fluidized bed to necessary minimum and granules strength increasing without destroying the internal crystalline structure.

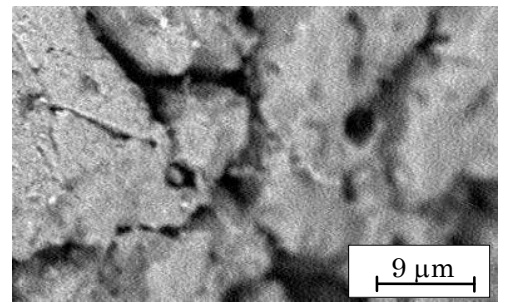

Fig. 6-Structure of granules at bottom supply of humidifier in granulator`s peripheral areas

If the granulators constriction has an element for granules humidification before entering in the working chamber via the latter conditions for uniform application of liquid material onto the granules surface. The granules that are moistened in this manner, has deep pores, high relative surface porous. In structure of porous layer curved channels are dominated, which increase granules ability to hold diesel fuel.

The results of studies concerning the influence the humidifier type to granule`s quality are given in Table 2. These results show that at almost equal value absorption capacity is depending on humidifier type, the granules have different holding capacity. This can be explained by the fact that different humidifier types are base for formation of various pores types with straight or tortuous channels. This conclusion can be taken as a starting assumption for further study nanoscale porous layer structure in different humidifiers types.

The granules absorption capacity is caused by pore`s characteristics and size, the holding capacity is caused by grain size and degree of their destruction. The research results also show that the humidifier type affects only to the absorption and holding capacity of granules. Strength of granules depends upon the granulator thermodynamic operation mode and granules drying time.

Microstructure and granulometric structure analysis of granules with porous surface layer showed that the increase the holding capacity value occurs only due to formation of developed pore structure and not due to expense of granules destruction. 
Table 2-The influence of humidifier type on granules quality (pre-wetting by method [17, 18], thermodynamic and hydrodynamic characteristics of granulator operation - according to [8])

\begin{tabular}{|l|c|c|c|}
\hline \multicolumn{1}{|c|}{ Type of humidifier } & $\begin{array}{c}\text { Strength, } \\
\mathbf{k g} / \\
\text { granule }\end{array}$ & $\begin{array}{c}\text { Absorption } \\
\text { capacity, } \\
\text { \% }\end{array}$ & $\begin{array}{c}\text { Holding } \\
\text { capacity, } \\
\text { \% }\end{array}$ \\
\hline Water & 0,4 & 8,3 & 9,6 \\
\hline Solution of ammonium nitrate & 0,4 & 8,4 & 10,1 \\
\hline Solution of ammonium nitrate and carbamide & 0,4 & 8,5 & 11 \\
\hline Solution of ammonium nitrate, carbamide and lauryl sulfate sodium & 0,42 & 8,5 & 11,4 \\
\hline
\end{tabular}

\section{CONCLUSIONS AND RECOMMENDATIONS}

Results of research allow to choose the optimal dispersant location (when humidifier dispersed directly into a vortex granulator), or the most effective conditions prior granules humidification. Comparative indicators of granules depending on humidifier type allow to state that hydration with nitrogenous fertilizer solutions with addition of surfactants is much more efficient than water hydration.

When using the expanded PAN heat treatment after detonation reaction industrial of slowing down as a result of defects in the crystal structure of the granules (the expansion of education-atoms in a crystal). In the obtained PAN samples through the use of new technology and lowering the temperature of the process, in the center of the nucleus after drying are air bubbles, which spo-top reaction proper detonation of industrial explosives detonation.

Experiments data are the basis of optimization selection granules humidification method (place of granules income to granulator, area of application of humidifier, humidification method, etc.). Among the future research challenges - impact assessment of humidifier and coolant temperature on quality of porous surface layer.

This work was carried out under the project «Improving the efficiency of granulators and dryers with active hydrodynamic regimes for obtaining, modification and encapsulation of fertilizers", state registration No. 0116U006812.

\title{
3-D наноструктурный пористый слой аммиачной селитры: влияние способа увлажнения на структуру слоя
}

\begin{abstract}
А.Е. Артюхов, В.И. Склабинский
Сулский государственный университет, ул. Римского-Корсакова, 2, 40007 Суль, Украина

Статья посвящена изучению влияния типа увлажнителя и способа увлажнения на структуру и качество пористого поверхностного слоя гранул аммиачной селитры. Предложены различные типы увлажнителей и показаны качественные характеристики пористой аммиачной селитры для каждого из них. Исследованы структура и показатели качества пористой аммиачной селитры при различном взаимном направлении движения гранул и увлажнителя. Предложен способ предварительного увлажнения гранул с их термообработкой в вихревом грануляторе. Полученные данные являются основой для создания методики инженерного расчёта вихревых грануляторов в составе установок получения 3-D наноструктурного пористого поверхностного слоя на грануле аммиачной селитры.
\end{abstract}

Ключевые слова: 3D Наноструктурированный Пористый слой, Вихревой гранулятор, Увлажнение

\section{D наноструктурний пористий шар аміачної селітри: вплив способу зволоження на структуру шару}

\author{
А.Є. Артюхов, В.І. Склабінський
}

\author{
Сулський державний університет, вул. Рилського-Корсакова, 2, 40007 Сули, Украйна
}

\footnotetext{
Стаття присвячена вивченню впливу типу зволожувача і способу зволоження на структуру і якість пористого поверхневого шару гранул аміачної селітри. Запропоновано різні типи зволожувачів $\mathrm{i}$ показані якісні характеристики пористої аміачної селітри для кожного з них. Досліджено структуру та показники якості пористої аміачної селітри при різному взаємному напрямку руху гранул $\mathrm{i}$ зволожувача. Запропоновано спосіб попереднього зволоження гранул з їх термообробкою в вихровому грануляторі. Отримані дані е основою для створення методики інженерного розрахунку вихрових грануляторів в складі установок отримання 3-D наноструктурного пористого поверхневого шару на гранулі аміачної селітри.
}

Ключові слова: 3D Наноструктурований Пористий Шар, Вихровий Гранулятор, Зволоження 


\section{REFERENCES}

1. Ammonium Nitrate Explosives for Civil Applications: Slurries, Emulsions and Ammonium Nitrate Fuel Oils (Ed. G.M. Erode) (Weinheim: Wiley-VCH Verlag \& Co: 2013).

2. D. Buczkowski, Cent. Eur. J. Energ. Mat. 8 No 2, 99 (2011).

3. S.A. Resende, V.C. e Silva, H.M. de Lima, Rem: Rev. Esc. de Min. 67 No 3, 297 (2014).

4. M. Dobrilović, V. Bohanek, S. Žganec, Cent. Eur. J. Energ. Mat. 11 No 2, 191 (2014).

5. A. Maranda, P. Koślik, J. Hadzik, Z. Wilk, Chemik 68 No 1, 9 (2014).

6. D. Buczkowski, Cent. Eur. J. Energ. Mat. 11 No 1, 115 (2014).

7. L. Tan, L.-H. Xia, Q.-J. Wu, S. Xu, D.-B. Liu, Combust. Explos. Shock Wave. 52, No 3, 335 (2016).

8. A.E. Artyukhov, V.I. Sklabinskyi, Nauk. Visnyk Nats. Hirnychoho Univ. 642 (2013).

9. A.E. Artyukhov, V.I. Sklabinskyi, Chem. Chem. Techn. 9 No 2, 175 (2015)

10. A.E. Artyukhov, V.I. Sklabinskyi, Chem. Chem. Techn. 9 No 3,337 (2015).
11. A.E. Artyukhov, Chem. Petrol. Eng. 49 No 11-12, 736 (2014).

12. M.G. Prokopov, D.A. Levchenko, A.E. Artyukhov, Appl. Mech. Mater. 630, 109 (2014).

13. A.E. Artyukhov, A.S. Fursa, K.V. Moskalenko, Chem Petrol. Eng. 51 No 5-6, 311 (2015).

14. N.A. Artyukhova, A.B. Shandyba, A.E. Artyukhov, Nauk. Visnyk Nats. Hirnychoho Univ, 1, 92 (2014).

15. A.E. Artyukhov, A.A. Voznyi, 6th International Conference Nanomaterials: Application \& Properties (NAP-2016) 5 No 2, 02NEA01 (2016).

16. A.E. Artyukhov, 6th International Conference Nanomaterials: Application \& Properties (NAP-2016) 5 No 2, 02NEA02 (2016).

17. A.E. Artyukhov, V.I. Sklabinskyi, K.V. Zheba. Pat. No. 90798, Ukraine Int. Cl B01J 2/16, B01J 8/08, B01J 8/18. publ. 25.05.2010, bul. No. 10 .

18. A.E. Artyukhov, V.I. Sklabinskyi Pat. No. 99023 Ukraine, Int. Cl B01J 2/00, B01J 2/16. publ. 10.07.2012, bul. No. 13 . 